\title{
Analysis of Behavioral Factors Influencing Investment Performance of Individual Investors in Nairobi Securities Exchange
}

\author{
Jackson Oyaro Ong'eta ${ }^{\text {a*1 }}$ and Eric J. Nasution ${ }^{2}$ \\ ${ }^{\text {a1 }}$ Department of Accounting and Finance, University of Eastern Africa, Baraton, Kenya \\ ${ }^{2}$ Adventist International Institute of Advanced Studies \\ DOI: 10.29322/IJSRP.11.11.2021.p11907 \\ http://dx.doi.org/10.29322/IJSRP.11.11.2021.p11907
}

\begin{abstract}
Investment decisions are usually influenced by various behavioural factors. The assumption is that herding, prospecting and heuristics influence personal investment decisions among investors in the stock market. The main objective of this study was to analyze the behavioral factors influencing investment performance of individual investors in Nairobi Security Exchange. The specific objectives of the study were; assess whether the following factors-herding, prospect (loss aversion, regret aversion, and escalating the commitment), heuristic (availability bias and overconfidence) and investment decisions-are significantly correlated with each other in the NSE and establish whether the following behavioural factors-herding, prospect (loss aversion, regret aversion, and escalating the commitment) and heuristic (availability bias and overconfidence) combined together significantly influence the investment performance in the NSE. The investigator hypothesized that $\mathbf{H}_{01}$ : The following behavioral factors-herding, prospect (loss aversion, regret aversion, and escalating the commitment) and heuristic (availability bias and overconfidence) and investment decisions-are not significantly correlated with each other in the NSE and $\mathbf{H}_{02}$ : the following behavioural factors-herding, prospect (loss aversion, regret aversion, and escalating the commitment) and heuristic (availability bias and overconfidence) combined together do not significantly influence the investment performance in the NSE. In order to achieve the set objective, the investigator adopted survey research design targeting 1,196,995 individual investors in Nairobi Securities Exchange. The Slovin's formula was used to estimate the 400 sample size of a population whereas the researcher took the high limit of 500 individual investors in Nairobi Securities Exchange. Structured questionnaire was used to collect primary data. The study established that loss aversion and overconfidence behaviour was displayed by the individual investors at a high level. The researcher recommends that The individual investors should be encouraged to avoid the influence of loss aversion. Instead, they should rely on fundamental analysis of the stocks to make decisions.
\end{abstract}

Key Words:Investment Performance, Investment Behaviour, Herding Behaviour, Prospect Behaviour, Heuristic Behaviour.

\subsection{Introduction}

Behavioural finance is emerging the field of finance and understanding of individual investor's behaviour towards stock market by the policy makers, institutions, market infrastructure institutions, and companies find is key in realizing acceleration of investment in stock by a country.Behaviour finance deals with the psychology of the human perspective of decision-making and inclined to intellective illusions (Ritter, 2003). Kengatharan and Kengatharan (2014) alluded that investment decision is influenced by behavioural factor. Market, prospect, heuristics and herding had significant effect with anchoring leading on investment decision, hence, choice of stock made was negatively affected by herding, just like overconfidence are some of these behavioural factors. These factors affect investors in the stock market world-wide including Nairobi Securities Exchange.

${ }^{1}$ Corresponding author Tel: (+254 722 252904). E-mail:ongetaj@ueab.ac.ke

This publication is licensed under Creative Commons Attribution CC BY.

http://dx.doi.org/10.29322/IJSRP.11.11.2021.p11907

WWW.ijsrp.org 
International Journal of Scientific and Research Publications, Volume 11, Issue 11, November 2021 ISSN 2250-3153

Conventional theories of finance assume individuals as rational investors (Baker \& Filbeck, 2013) while taking investment decisions they are evaluating all existing information, several researchers reveal that investors act irrationally. Behavioural finance proposes that investors show psychological and emotional behaviour which follows to divergence from rational behaviour (Yoong \& Ferreira, 2013). Olsen (2001) also asserts that behavioural finance seeks to understand and predict systematic financial market implications of psychological decision process. "Behavioural finance, as a part of behavioural economics, is that branch of finance that, with the help of theories from other behavioural sciences, particularly psychology and sociology, tries to discover and explain phenomena inconsistent with the paradigm of expected utility of wealth and narrowly defined rational behavior.

There are several biases in human psychology (Hoffmann et al., 2010). These biases contain investors' extremely appreciating their predictions (overconfidence), investors more likely to hold losing stock and sell winning stock (disposition), individual investors avoid taking the risk (risk-aversion) and investors follow the crowd (herding). Several research studies also try to enlighten investor behaviour considering several dimensions in addition to investors' biases. Overconfidence bias mean when investor extremely intensifying their predictions while investing (Budiarto, 2017). Overconfidence of individual investors has significant effect on the investment decisions (Pradikasari and Isbanah, 2018). Bakar and Yi (2016) reveal that overconfidence bias has a significant negative impact on investors' decision-making.

Investment decisions are made by investors and investment managers. Investors commonly perform investment analysis by making use of fundamental analysis, technical analysis and judgment. Investment decisions are often supported by decision tools. It is assumed that information structure and the factors in the market systematically influence individuals' 4 investment decisions as well as market outcomes. Investor market behavior derives from psychological principles of decision making to explain why people buy or sell stocks. Individual investors differ from institutional investors in terms of their investment profiles, investment horizons and the amount of money expended on an investment venture.

An individual investor is one person acting on his own accord as a private entity; while institutional investors are mostly companies. They include entities such as hedge funds, insurance companies, pension funds, commercial banks, mutual funds and endowment funds. Institutional investors have an edge over the private individuals because their investments are managed by professionals, have a large capital base and have access to a wide array of securities to invest in (NSE, 2016). Duong et al. (2015) found that investor's knowledge and their decisions about investment and savings can be enhanced at their age of retirement and it seems that demographic factors like gender, age, income are associated with the behaviour of the investor. Ates, a et al. (2016) describes a substantial association amongst behavioural biases variables and the level of financial literacy.

\subsection{Statement of the Problem}

This influence of behavioural factors on investors has resulted in anomalies in the securities market leading to major losses on investments made. In the recent past, it has been noted that equities in the financial market have done well while individual investors reported losses in NSE (Vijaya, 2014). The underperformance of individual investors to a large extent may be due to factors related to the individual investors' behaviour and not performance of the securities market.

Different authors have taken different psychological factors in relation to investment decisions. Overconfidence influences their own decisions as a result of mood, feelings, intuition and emotion and considers their results rational and seek evidence to support their viewpoint and neglect the contradicting evidence. Qadri and Shabbir (2014); Qureshi, Rehman, and Hunjra (2014) and Bashir, Azam, Butt, Javed, and Tanvir (2013) have found that overconfidence influence the investor's investment decisions significantly positive, but 
the studies of Kafayat (2014) and Kengatharan \& Kengatharan (2014) showed a negative relationship between overconfidence and decision making. Confident investors trade more than less confident investors (Hoffmann \& Post, 2016). Empirical studies on behavioural factors of individual investment in Nairobi Securities Excahnge are not adequately carried out in Kenya.A deeper investigation of individual investors' behaviour is, thus, warranted. Therefore, this study aimed to research on the behavioural factors (herding, prospect, and heuristic).

The investigation specifically assessed whether the following factors-herding, prospect (loss aversion, regret aversion, and escalating the commitment), heuristic (availability bias and overconfidence) and investment decisions-are significantly correlated with each other in the NSE. Secondly, the investigation assessed whether the following behavioural factors-herding, prospect (loss aversion, regret aversion, and escalating the commitment) and heuristic (availability bias and overconfidence) combined together significantly influence the investment performance in the NSE. In order to answer these objectives, the study tested the following hypotheses; H01: The following behavioral factors-herding, prospect (loss aversion, regret aversion, and escalating the commitment) and heuristic (availability bias and overconfidence) and investment decisions-are not significantly correlated with each other in the NSE.H02:the following behavioural factors-herding, prospect (loss aversion, regret aversion, and escalating the commitment) and heuristic (availability bias and overconfidence) combined together do not significantly influence the investment performance in the NSE.

\subsection{Literature Review}

\subsection{Theoretical Review}

\section{Prospect Theory}

This theory was developed by Kahneman and Tversky (1979). The theory focuses on subjective decision-making influencing investors' value system (Filbeck \& Horvath, 2005). This theory can be attributed to Kahneman et al., (1979). The theory represents a major paradigm in the field of decision making under uncertainty. Drawing from an assumption of bounded rationality, prospect theory suggests that individuals will exhibit variable risk preferences in differing contexts, and may be either risk averse or risk seeking, depending on how they frame decision problems (Holmes, Bromiley, Dervers, Holcomb, \& Mcguire, 2011). Prospect theory argues that people exhibit loss aversion, which means that they are more sensitive to losses than to gains when having to make decisions under risk hence the appropriateness of the theory in analyzing the Behavioral Factors Influencing Investment Performance of Individual Investors in Nairobi Securities Exchange.

\section{Heuristic Theory}

Heuristics are defined as the rules of thumb, which makes decision making easier, especially in complex and uncertain environments (Ritter, 2003) by reducing the complexity of assessing probabilities and predicting values to simpler judgments. In general, these heuristics are quite useful, particularly when time is limited, but sometimes they lead to biases (Waweru et al., 2008). The decision process by which the investors find things out for themselves, usually by trial and error, lead to the development of rules of thumb. In other words, it refers to rules of thumb which humans use to made decisions in complex, uncertain environments (Ritter, 2003). The reality, the investors decision making process are not strictly rational one. Though the investors have collected the relevant information and objectively evaluated, in which the mental and emotional factors are involved. It is very difficult to separate. Sometimes it may be good, but many times it may result in poorer decision outcomes. The theory is appropriate for the study so as to explain the the Behavioral Factors Influencing Investment Performance of Individual Investors in Nairobi Securities Exchange. 
Modern Portfolio Theory (MPT)

It is one of the most important and influential economic theories dealing with finance and investment, MPT was developed by Harry Markowitz in the year 1958 and published under the title "Portfolio Selection". It is the creation of economists who try to understand the market as a whole, rather than business analysts who look for what makes each investment opportunity unique. Investments are described statistically in terms of their expected long-term return rate and their expected short-term volatility. The volatility is equated with risk, measuring how much worse than average an investment's bad years are likely to be. The goal is to identify the acceptable level of risk tolerance and then to find a portfolio with the maximum expected return for that level of risk. The key tenet of Modem portfolio theory therefore is that if one wishes to increase the performance and reduce the risk in an overall investment portfolio, he or she should combine investments that are non-correlated with one another (Thaler \& Shefrin. 1981). MPT is relevant to this study an investing portfolio has long term goals independent of a market's Day today fluctuations; because of these goals, investment portfolio theories aim to aid investors in decision making.

\subsection{Empirical Review}

Adil, Singh and Ansari (2021) examined the impact of behavioural biases on investment decisions amongst gender. The authors further examine the moderation effect of financial literacy in the relationship between behaviour biases and investment decisions amongst gender. The study considered a cross-sectional research design. For this survey, the data have been collected through a structured questionnaire from 253 individual investors of the Delhi-NCR region. For testing the hypothesis, hierarchical regression analysis has been used in the study. The results of the study reveal that amongst male investors, the influence of risk-aversion and herding on investment decision was negative and statistically significant, while the influence of overconfidence on investment decision was positive and significant. However, the influence of disposition was found statistically insignificant. The results stated that amongst female investors the effect of risk-aversion and herding on investment decision was negative and statistically significant. However, the effect of overconfidence and disposition was statistically insignificant influence the investment decision. Adil, Singh and Ansari (2021) was based on behavioural biases on investment decisions amongst gender as opposed the current investigation which analyzed the behavioral Factors Influencing Investment Performance of Individual Investors in Nairobi Securities Exchange.

Rasool and Ullah (2019) determined the relationship between financial literacy and behavioural biases of individual investors in Pakistan. A sample of 300 observations was obtained through questionnaires from individual investors residing in Lahore and invested in Pakistan Stock Exchange. The hypothesis developed for the research was tested by Pearson's Chi-square and Ordinal Regression Analysis. The hypothesis testing of the research concluded that there is a negative association between financial literacy and behavioural biases of individual investors. So, it means; with an increase in level of financial literacy, the likelihood of investor facing behavioural biases reduces. It also appeared that male respondents have more financial literacy than female respondents Originality/value - Previous studies in the field of finance, identified different factors causing the financial behaviour of individual investor of Pakistan, and also focused on level of financial literacy in Pakistan, but these studies have not emphasized the crucial relationship between financial literacy and behavioural biases of individual investors. Thus, the unique empirical analysis developed in this paper has accentuated the financial literacy as a factor that mitigates behavioural biases of individual investor. Rasool and Ullah (2019) study determined the relationship between financial literacy and behavioural biases of individual investors in Pakistan whereas the current study analyzed the behavioral Factors Influencing Investment Performance of Individual Investors in Nairobi Securities Exchange. 
Raheja and Dhiman (2020) examined the impact of behavioral factors and investors psychology on their investment decision-making. The information was gathered from 500 financial specialists. The region of research was the financial specialists who contribute through LSC Securities Ltd. in Punjab State. The purposive testing system was used in this examination. The investigation found that the positive connection between the conduct predispositions of the financial specialists and venture choices of the speculators and positive connection between enthusiastic insight of the financial specialists and their venture choices. Yet, the authors found that the enthusiastic insight better foresees the venture choices of the financial specialists than the conduct predispositions of the speculators. Among the different elements of conduct inclinations of the speculator's lament and carelessness are identified with the financial specialist's venture choices. Among the various estimations of eager understanding - care, dealing with emotions, motivation, empathy and social aptitudes are related to the hypothesis decisions of the monetary pros. Raheja and Dhiman (2020) examined the impact of behavioral factors and investors psychology on their investment decision-making whereas the current investigation specialized only on the behavioural factors among individual investors in Nairobi Securities Excahnge.

Bagodi and Sagar (2021) studied the factors that influence the investor's investment decision in Indian stock market consisting of 10 sectors with 30 companies listed on BSE-30 SENSEX. A research instrument consisting of 14 attributes was designed and sent to 2100 respondents. 467 responses were collected over a period of 6 months and KANO model was developed to classify the information into 'must be', 'linear', and 'delight' attributes. It was found that 'must be' attributes include condition of financial statements, current economic indicators, and the result of technical analysis and 'insider information' is a 'delight' attribute. The study revealed the factors are affecting the decision making of investors. The consideration of factors for investment decision making is sector specific and helps various parties in understanding the investment decision behaviour of investors.' This study analyzed broadly the actors that influence the investor's investment decision in Indian stock market whereas the current study investigated the behavioral Factors Influencing Investment Performance of Individual Investors in Nairobi Securities Exchange.

Kimeu, Onyango and Rotich (2016) examined the behavioural factors influencing individual's investment decision in Nairobi Securities Exchange. Specifically, the research sought to examine the relationship between prospect factors, heuristic factors, herding factors, rationality and investment decision. The research was guided by prospect, herding, heuristic and Expected Utility theories of behavioural finance. The research population was individual investors who had invested in both equity and bonds in the Nairobi Securities Exchange as at the end of third quarter of 2015. The study came up with a sample size of 80 respondents. Simple random sampling technique was used to determine the respondents of the study. Primary data was collected through the use of closed ended questionnaires, pick and drop procedure was used to collect data through the use of registered offices of stock brokers. Descriptive statistics such as mean and standard deviation was used in data analysis. Inferential statistics which included correlation analysis and regression analysis was also used in interpreting the results of the study. Tables and graphs were used to present the data collected for ease of understanding. The results of the study shows that investment decisions in the Nairobi Securities Exchange are positively influenced by behavioural factors including prospect, herding, heuristic and rationality.

Velumoni (2017) did an analysis of prospect theory on equity investment decision making. The research adopted prospect theory which examined on the mental accounting, loss aversion and regret aversion. It used primary data that were collected from 303 respondents who are equity shares investors. Linear regression, t-test and ANOVA were used as inferential tools. The study found no significant difference between behavioural factors and socio demographic variables. Behavioural factors based on prospect theory had significant influence on the investment decision. Duclos (2015) study on psychology of investment behaviour focused on the biasing financial decision making one graph at a time. The research investigates on the behaviour associated with the way manager develop graphical displays for financial information where they need to project the future trends and make investment decision based on the This publication is licensed under Creative Commons Attribution CC BY. 
information. Velumoni (2017) study was based on prospect theory on equity investment decision making compared to the current study which analyzed the behavioral factors influencing investment performance of individual investors in Nairobi Securities Exchange.

Duclos (2015) considered five investors as an experiment and found that the last trading day of stock provided excessively information that was important to the investor known as end-anchoring. Considerably investors would treat stock closing upward would focus upwards forecasts in the following day likewise to downward focus. Investment asymmetries indicated that stock-price distributions were produced randomly to simulate times and hence market conjuncture is hesitant hence no real upward or downward trend is identified.

Luu (2014) conducted a study on behavioral factors influencing the decisions of individual investors at the securities companies in Vietnam. The study assessed the effect of five behavioral factors; herding, market, prospect, overconfidence and anchoring. The study sampled 300 individual investors selected randomly from the investment companies. The questionnaires were used to collect data, from the 300 questionnaires given, 188 were returned duly filled. The data were analysed using descriptive statistics; mean and standard deviations. The current study will be done in Kenya focusing on the four behavioral factors which include herding, prospect, overconfidence and anchoring avoiding market which is not a heuristic behaviour rather than anexternal factor. This study adopts descriptive research design and the use of questionnaires. Luu (2014) study was conducted in Pakistan whereas the current study was conducted among the individual investors in Nairobi Securities Exchange.

Barno and Tuwei (2020) sought to determine the effect of prospect bias on investment decisions among small and micro enterprises in Nairobi County. The specific objectives of the study were to: determine the effect of overconfidence, anchoring, prospecting and herding on investment decision making as well as to investigate the moderating effect of financial literacy on the relationship between overconfidence, anchoring, prospecting, herding and investment decisions among Small and Micro Enterprises. The study was premised prospects theory. Positivism paradigm was deployed. The study adopts explanatory research design. The target population were 102,821 firm owners. A sample of 383 respondents was selected using stratified random sampling technique. The findings from regression model showed results revealed that prospect factors had a positive and significant influence on investment decision $(\beta=$ $0.288, \mathrm{p}=0.00$ ). Barno \& Tuwei (2020) study was based only on prospect factor whereas the current investigation was based on all the behavioural factors.

Ratnadi, Widanaputra and Putra (2020) examined the effect of behavioral factors in investment decision-making. This study examines behavioral factors (Heuristics, Prospects, Market, and Herding) that influence stock investment decisions by College students. This research was conducted in the province of Bali-Indonesia. Data were collected by survey method through questionnaires. The respondents were students who have invested in shares. Data were analyzed using multiple linear regression. The proxy of behavioral factors is determined by factor analysis. The analysis results show that the heuristic behavior factor carried out by students in investment decisions is availability bias. Prospect behavior factor is mental accounting, market behavior is past stock price trends, and the forming factor of herding behavior is the speed with which other investors react. The results of multiple linear regression analysis showed that heuristic, did not affect investment decisions, prospect factors influenced investment decisions, market behavior factors influenced investment decisions and herding had a negative effect on investment decisions. This study was conducted in Indoasia whereas the current investigation was conducted the among individual investors in Nairobi Securities Exchange. 
Rihaz, Ahamed, Parkash and Ahamed (2020) investigated those determinants, which affected the extent of stock market investors' behavior in Pakistan during spread of COVID-19. Data was collected from various individual investors, representing a high response rate of about $86.5 \%$ from 167 respondents. From the analysis it was indicated that most important and significantly influencing determinants on investment decisions in Pakistan Stock Markets are pertinent to: 'getting rich quickly, loss aversion, fear of losses, expected corporate earnings and dividends, gut feelings on the economy, previous performances of firm's stock and opinions of its majority shareholders, and eventually, the recommendations of brokers and family/friends. Our findings would first, assist in understanding the most common behavioral patterns of investors and secondly, determine to show the adequate paths, which lead towards the growth of Pakistan Stock Market. Rihaz, Ahamed, Parkash, Ahamed (2020) study was based investors behavior based on COVID-19 whereas the current investigation was conducted in Kenya in 2018 before Coivd-19.

Iqbal, Haq and Muhamad (2020) investigated the influence of psychological factors such as confidence, optimism, loss aversion and herding behaviour could affect investment decisions in KP's SMEs. The pilot study carried out initially. The study surveyed 249 samples through simple random technique through self-administrative questionnaires as previously no questionnaire available. The reliability of the questionnaire is 0.71 Cronbach's Alpha Static and validity of the questionnaire is checked through Exploratory Factor Analysis (EFA). The study uses the descriptive statics, frequency and binary logistic regression used. The mean value of psychological factors is 3.81 shows a high impact on investment decisions, with $66 \%$ of investors has shown positive concern over psychological factors and considering it motivational factor for investment decisions. The result binary logistic model revealed that all sub-factors of psychological are positively significant with investment decision except the loss aversion. The probability of investing in the presence of confidence (79.59\%), optimism (89.90\%), loss aversion (64.29\%), herd behaviour (88.37\%) and overall psychological factors (80.54\%) in KP's SMEs. Hence it can be concluded that investors are rational and their investment decisions in SME's at times influence by psychological factors. Iqbal, Haq and Muhamad (2020) study was conducted among SMEs in Khyber Pakhtunkhwa whereas the current study was analyzed the behavioral factors influencing investment performance of individual investors in Nairobi Securities Exchange.

\subsection{Conceptual Framework}

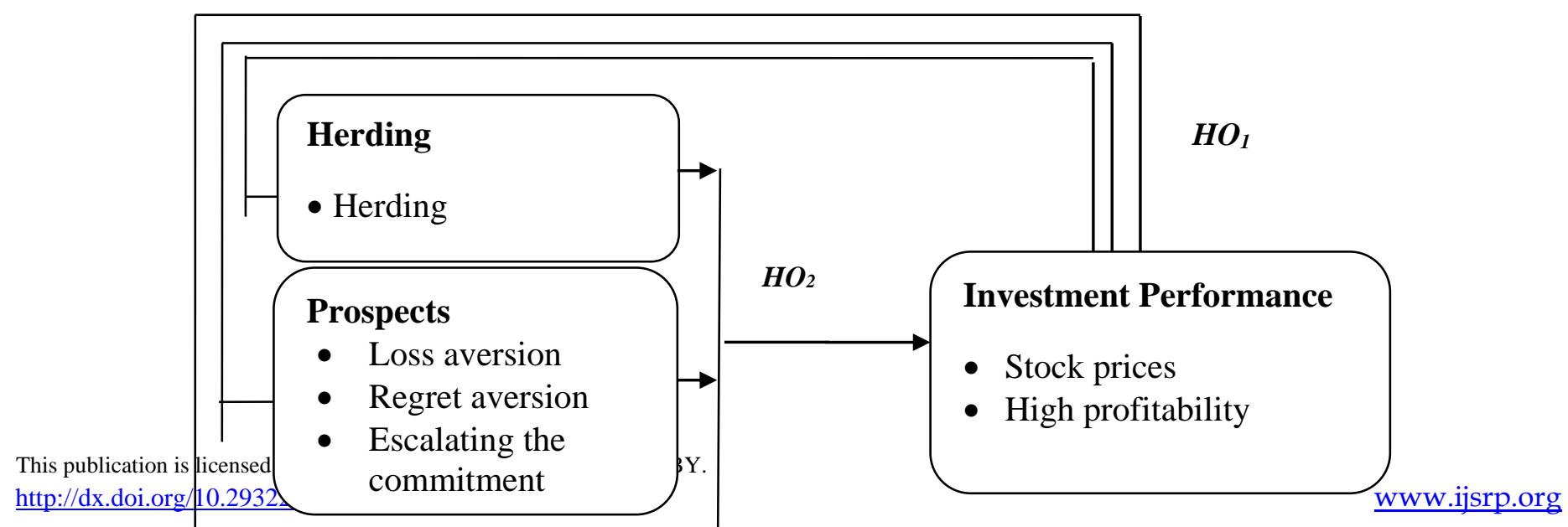

(Dependent Variable) 


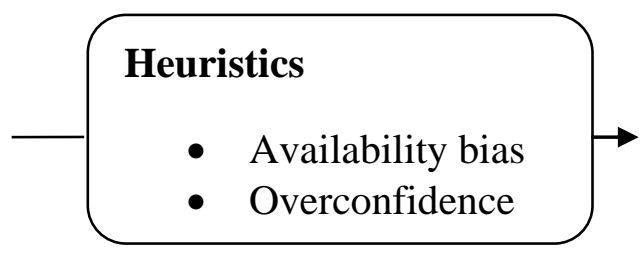

(Independent Variables)

\section{Figure 1: Conceptual Framework}

Figure 1 shows the relationships among the variables. The independent variables consisted of the behavioural and the market factors. The dependent variable was the behavioural factors influencing individual investors' investment decision (Herding, prospects and heuristics).

\subsection{Methodology}

The investigationadopted survey research design targeting 1,196, 995 individual investors in Nairobi Securities Exchange. The Slovin's formula was used to estimate the sample size of a population that will be representative(Kalima, Shukla, \& Mbabazize, 2016). The formula is given as follows:

$$
\begin{gathered}
\mathrm{n}=\underline{\mathrm{N}} \\
\begin{array}{c}
1+\mathrm{Ne}^{2} \\
\text { Where: } \mathrm{n}=\text { Sample size } \\
\mathrm{N}=\text { Total population } \\
\mathrm{e}=\text { Error margin }(0.05) \\
\mathrm{n}=\underline{1,196,995}
\end{array}
\end{gathered}
$$

$1+1,196,995(0.05)^{2}$

$\mathrm{n}=\underline{1,196,995}$

2993.4875

$\mathrm{n}=399.87$

Therefore, the sample size was 400,but, the researcher aimed at a sample size of 500. Stratified sampling method was used to identify the brokerage firms. The stratification was based on the brokerage firms listed with the NSE. This sample size was distributed to the selected brokerage firms equally. Convenient sampling was used to identify the 500 respondents from the selected brokerage firms. The investigator used structured questionnaire with closed-ended questions was used to collect primary data from the individual investors in the stock exchange.

Data was analyzed using; Pearson Correlation,Simple Linear Regression and Hierarchical Linear Regression Analysis. The following model was used to test the hypotheses.

$$
I P=\propto+\beta_{1} H F+\beta_{2} P F+\beta_{3} H U F+\varepsilon
$$


Where:

$$
\begin{aligned}
& \mathrm{I} P=\text { Investment Performance } \\
& \alpha=\quad \text { Intercept } \\
& \beta=\quad \text { Regression coefficients } \\
& \mathrm{HF}=\quad \text { Herding Factor } \\
& \mathrm{PF}=\quad \text { Prospect Factor } \\
& \text { HUF }=\text { Heuristic Factor } \\
& \varepsilon=\quad \text { Error term } \\
& \beta_{1}, \beta_{2}, \beta_{3} \text {, Represents coefficients }
\end{aligned}
$$

\subsection{Results}

\subsection{Findings of Individual Behavioural Factors and Investment Performance}

The first objective of the investigation was to assess whether the following factors-herding, prospect (loss aversion, regret aversion, and escalating the commitment), heuristic (availability bias and overconfidence) and investment decisions-are significantly correlated with each other in the NSE.This section attempted to answer research question four: Are the following factors: herding, prospect (loss

\begin{tabular}{|c|c|c|c|c|c|c|c|c|}
\hline & $\mathrm{HE}$ & LA & RA & EC & $\mathrm{AB}$ & $\mathrm{OV}$ & IP & \\
\hline $\mathrm{HE}$ & 1 & & & & & & & significant at \\
\hline LA & $.934^{* * *}$ & 1 & & & & & & the 0.01 level \\
\hline RA & $.894^{* * *}$ & $.706^{* *}$ & 1 & & & & & (2-tailed). \\
\hline EC & $.874^{* *}$ & $.906^{* *}$ & $.706^{* *}$ & 1 & & & & \\
\hline $\mathrm{AB}$ & $.767^{* *}$ & $.589^{* *}$ & $.731^{* *}$ & $.589^{* *}$ & 1 & & & The \\
\hline $\mathrm{OV}$ & $.185^{* *}$ & $.094^{*}$ & $.097^{*}$ & $.094^{*}$ & $.688^{* *}$ & 1 & & correlation \\
\hline IP & $.155^{* *}$ & $.116^{* *}$ & .019 & $.116^{* *}$ & $.589^{* *}$ & $.850^{* *}$ & 1 & was \\
\hline
\end{tabular}
aversion, regret aversion, and escalating the commitment), heuristic (availability bias and overconfidence), market factors (public information and expert information), and investment decisions significantly correlated with each other in the NSE? To answer this question, correlation analysis was done to determine the relationships and the strength of relationship among the herding (HE), loss aversion (LA), regret aversion (RA), escalating the commitment (EC), availability bias (AB), overconfidence (OV), public information (PI), expert information (EI) and investment decisions (ID) on the dependent variable- investment performance (IP).

\section{Correlation Analysis}

Table 1:Correlation for the Independent Variables with the Dependent Variable 
using the SPSS among six behavioral variables, two market variables, and one control variables that influence investment performance (see Table 1. There is a significant strong positive correlation between investment decisions and investment performance $(\mathrm{r}=.828, \mathrm{~N}=498, p<.01$, two tailed). This means that for every increase in investment decisions there is a positive increase in investment performance. There is a strong positive correlation between overconfidence and investment performance $(\mathrm{r}=.850, \mathrm{~N}=$ $498, p<.01$, two tailed). This means that $85 \%$ variation in investment performance can be attributed to overconfidence behaviour. There is also a strong positive correlation between availability bias and investment performance $(\mathrm{r}=.589, \mathrm{~N}=498, p<.01$, two tailed). This shows that for every increase in availability bias there is a positive increase in investment performance.

There is a weak positive correlation between herding and investment performance $(\mathrm{r}=.155, \mathrm{~N}=498, p<.01$, two tailed). This means that only $15.5 \%$ of the variation in investment performance is attributed to the herding behaviour. There is a weak positive relationship between regret aversion and investment performance which is not significant $(\mathrm{r}=.019, \mathrm{~N}=498, p>.01$, two tailed). There is a weak positive correlation between escalating commitment and investment performance $(\mathrm{r}=.116, \mathrm{~N}=498, p<.01$, two tailed). Therefore, $11.6 \%$ significant variation of investment performance can be accounted for by escalating the commitment.

The herding variable was highly correlated with loss aversion $(\mathrm{r}=.934, \mathrm{~N}=498, p<.01)$, regret aversion $(\mathrm{r}=.894, \mathrm{~N}=498, p<.01)$ and escalating the commitment $(\mathrm{r}=.874, \mathrm{~N}=498, p<.01)$. This variables were scrutinized to establish their contribution to the overall model such that we omit from the model the ones that contributes less. The loss aversion and escalating the commitment was also highly correlated $(r=.906)$ meaning that they should also be considered for elimination from the predictive model. However, the high correlation of the independent variables with the dependent variable does not affect the model. This is desirable since it shows that the independent variables are good predictors of the dependent variable. 


\subsection{Findings of Combined Behavioural Factors and Investment Performance}

Table 2: Model Summary of Combined Behavioural Factors and Investment Performance

\begin{tabular}{lcccc}
\hline Model & $\mathrm{R}$ & $\mathrm{R}$ Square & Adjusted R Square & $\begin{array}{c}\text { Std. Error of the } \\
\text { Estimate }\end{array}$ \\
\hline 1 & $.882^{\mathrm{a}}$ & .778 & .776 & .32035 \\
\hline
\end{tabular}

The findings of the multiple regression (see Table 2) show that herding, escalating the commitment, availability bias, overconfidence, and public information collectively predict investment performance by $\left(\mathrm{R}^{2}=77.8 \%\right)$ will all values being $p<.05$. The model was statistically significant $(\mathrm{F}[6,491]=287.587, p=.000)$ and therefore, a good model for predicting investment performance (see Table 3 ). The regression equation was derived from the unstandardized beta coefficients (see Table 4).

Table 3: ANOVA Regression Results

\begin{tabular}{llccccc}
\hline Model & Sum of Squares & df & $\begin{array}{c}\text { Mean } \\
\text { Square }\end{array}$ & F & Sig. \\
\hline \multirow{2}{*}{1} & Regression & 177.076 & 6 & 29.513 & 287.587 & $.000^{\mathrm{b}}$ \\
& Residual & 50.387 & 491 & .103 & & \\
& Total & 227.463 & 497 & & & \\
\hline
\end{tabular}

a. Dependent Variable: Investmentperformance

b. Predictors: (Constant), Escalatingcom, Availabilitybias, Overconfidence, Herding

Table 4: Coefficients of Market Efficiencies Impact on Investment Performance Model

\begin{tabular}{|c|c|c|c|c|c|}
\hline \multirow[t]{2}{*}{ Model } & \multicolumn{2}{|c|}{$\begin{array}{l}\text { Unstandardized } \\
\text { Coefficients }\end{array}$} & \multirow{2}{*}{$\begin{array}{c}\text { Standardized } \\
\text { Coefficients } \\
\text { Beta }\end{array}$} & \multirow[t]{2}{*}{$\mathrm{t}$} & \multirow[t]{2}{*}{ Sig. } \\
\hline & B & $\begin{array}{l}\text { Std. } \\
\text { Error }\end{array}$ & & & \\
\hline (Constant) & 3.102 & .223 & & 13.914 & .000 \\
\hline
\end{tabular}




$\begin{array}{lccccc}\text { Herding } & -.952 & .121 & -1.210 & -7.843 & .000 \\ \text { Escalatingcom } & .603 & .075 & .776 & 8.053 & .000 \\ \text { Availabilitybias } & .540 & .086 & .654 & 6.260 & .000 \\ \text { Overconfidence } & .129 & .049 & .197 & 2.637 & .009\end{array}$

Overconfidence

The model showed that the predictors explained $77.8 \%$ in the variance of investment performance. This means that the performance will vary by $77.8 \%$ when investors use the predictors in investment decision making.Herding behaviour was conceptualized to have a positive relationship with investment performance. But the model indicated a negative relationship between herding and investment performance. This relationship is supported by the herding theory which notes that there are two type of herding: spurious and intentional herding (Bikhchandani \& Sharma, 2000). The spurious herding occurs when the individual investors have the same set of information and hence, do analysis to arrive at the same conclusions. This will make them appear to be herding which may lead them to have positive relation between herding and investment performance. On the other hand, intentional herding may lead to negative relationship between herding and investment performance since investors do not do analysis before making investment decisions. This kind of herding is likely to lead to negative investment performance.

Escalating the commitment was postulated to have a negative relationship with investment performance. However, the model showed a positive relationship with the investment performance. The escalation of the commitment will have a negative relationship with investment performance when investors escalate the commitment for short period of time (Lin et al., 2014). But, if they escalate the commitment and hold the stocks for a longer period of time, they are likely to earn a positive return because the stock prices may increase in the long run.

Availability bias positively influences investment performance. This means that as availability bias increases investment performance will also increase. The available information could be the companies that are performing well in the stock market. Therefore, if individual investors increase in the use of well performing companies information to invest in such companies, their investment performance is also likely to increase. Overconfidence had a positive influence on investment performance. Therefore, an increase in overconfidence leads to the increase in investment performance. Overconfidence is when the individual investors overestimate their private information. The believe that they have better information leads them to trade more (Barberis \& Thaler, 2003). When the individual investors trade more they earn a positive return but it is less than the market return because of the trading costs.

\subsection{Conclusions, Recommendations and Limitations 5.1 Conclusions}

The findings indicated a high level of herding among the individual investors of NSE. This indicated that the individual investors displayed highly the herding behaviour when making investment decisions in the NSE. The discussion of the finding is provided. The high level of herdingdisplayedby the individual investors of NSE occurs when the individual investors follow the decisions of other investors so as to be like them. In addition, the investors may herd when they do not do their own analysis before making investment decisions. On the other hand, the individual investors follow the popular opinion in the stock market. This high level of herding is caused by the feeling of the herding investors that the others may be right or may possess information that they do not have. The investors who exhibit herding, may be encouraged to herd when they do not possess necessary knowledge and skills to evaluate investment for investment decision making. Therefore, they rely on the decision of other investors to make their own investment 
decisions. This findings show that the individual investors are influenced by herding behaviour. These levels are high which may affect their investment performance. This should be a source of concern for the individual investors, NSE management, and Capital Market Authority.

The finding of the study showed that loss aversion behaviour was displayed by the individual investors at a high level. This means that the individual investors were affected by loss aversion when making investment decisions. The interpretation of the finding is provided. The findings indicated that the individual investors make investment decisions in order to avoid incurring losses. This occurs when a positive return in the past would lead the individual investor to seek more risk. Consequently, when the return from past investment are positive the individual investors would invest in more risky investments in the hope that it would be a positive return and hence, exposing themselves to more risk. On the other hand, if an individual investor experienced a negative return in the past he/she will be more risk averse. This is because the thought of incurring a loss again is more painful than the gain being promised by the investment.

This finding shows that the individual investors display the loss aversion that may affect their investment performance. The NSE management and Capital Market Authority should organize seminars for the individual investors to sensitize them on the influence of loss aversion. The individual investors should be sensitized on the effect of loss aversion. In addition, they should be encouraged to make their own analysis of investments before making decisions to avoid loss aversion behaviour. The loss aversion may affect their investment performance.

The findings indicated that the individual investors of NSE had overconfidence level of which was high. This level means that the individual investors of NSE are influenced by overconfidence. The interpretation of the finding is provided. These findings indicate that the individual investors of NSE are affected by overconfidence when making investment decisions. This overconfidence of the individual investors occurs when they trade more in terms of buying and selling stocks. Therefore, those individual investors who are more confident will trade more in the stock market than the less confident ones. In other words, the overconfident individual investors think that they can beat the market. Overconfidence of the individual investors occur due to mis-calibration and the better-thanaverage effect. Mis-calibration occurs when the individual investors overestimate their abilities and hence, they are more accurate in their estimate of stock prices. Also, better-than-average effect is where the individual investors rate themselves to be better than other investors in the stock market. The individual investors of NSE are influenced by the overconfidence when making investment decisions. Studies have confirmed that it is not easy to beat the market. Therefore, it calls for the individual investors to be enlightened on the effect of overconfidence so that they can avoid it. The reduction of overconfidence may improve their investment performance.

\subsection{Recommendations}

The individual investors should be encouraged to avoid the influence of loss aversion. Instead, they should rely on fundamental analysis of the stocks to make decisions. This will make them earn market return, thereby avoiding the negative effect of loss aversion. In other words, the individual investors should avoid seeking more risk when the past returns have been positive while at the same time avoiding being risk averse just because the past returns were negative. The individual investors may end up losing if he/she relies on loss aversion without analyzing the investment opportunities. The study recommends that the individual investors should avoid considering themselves overconfident. The individual investors should not be tempted to overestimate their abilities. The individual investors should not rate themselves to be better than other investors in the stock market. This is because they may be encouraged to trade more which may affect their investment performance. 


\subsection{Limitation of the Study}

This study was limited to analysis of behavioral factors influencing investment performance of individual investors in Nairobi Security Exchange. Investment in any stock market is highly clustered for example in Nairobi Securities Exchange stock market is clustered into various segments. Researchers would be interested in understanding which market segment is influenced more by herding, prospects and heuristic factors. A further study that assesses behavioral factors influencing investment performance based on investment segment world further narrow this gap of which the current study did not analyze.

\subsection{References}

Adil, M., Singh, Y. \& Ansari, M.S. (202). How financial literacy moderate the association between behaviour biases and investment decision? Asian Journal of Accounting Research, 5(1), pp. 2443-4175.

Baker, H.K. \& Filbeck, G. (Eds) (2013), Portfolio Theory and Management, Oxford University Press.

Bakar, S. \& Yi, A.N.C. (2016). The impact of psychological factors on investors' decision making in Malaysian stock market: a case of Klang Valley and Pahang. Procedia Economics and Finance, Vol. 35, pp. 319-328.

Bagodi, V. \& Sagar, P. (2021). A study of factors affecting investment decisions in India: The KANO way.Asia Pacific Management Review, 3(1).

Barno, L.J. \& Tuwei, J.K. (2020). Effect of Prospecting Bias on Investment Decision Making among Small and Medium Enterprise in Nairobi County. Journal of Business Management and Economic Research, 4(3), pp. 253-266.

Bashir, T., Azam, N., Butt, A. A., Javed, A., \& Tanvir, A. (2013). Are behavioral biases influenced by demographic characteristics \& personality traits? Evidence from Pakistan. European Scientific Journal, 9(70), 277-293.

Bikhchandani, S., \& Sharma, S. (2000). Herd behavior in financial markets. IMF Staff Papers, 47(3), 279-310. http://doi.org/10.2139/ssrn.228343

Budiarto, A. (2017). Pengaruh financial literacy, overconfidence, regret aversion bias, danrisk tolerance terhadap keputusan investasi (studi pada investor PT. Sucorinvest central gani galeri investasi BEI universitas negeri surabaya). Jurnal Ilmu Manajemen (JIM), 5(2), pp. 1-9.

Cherotich, M. (2020). Investor behavior and common stock investment decisions among individual investors at Nairobi Securities Exchange, Kenya. Unpublished Thesis, Kenyatta University, Kenya.

Filbeck, G..Hatfield, P. and Horvath, P. (2005). Risk aversion and personality type. Journal of Behavioural Finance, 6 (4), $170-180$.

Iqbal, M.M.W., Haq, S.G. \& Muhamad, L. (2020). Psychological Factors Affecting the Investment Decisions in the Promotion of Small and Medium Enterprises (SMEs) In Khyber Pakhtunkhwa. International Review of Management and Business Research, 9(2), 255-270.

Kafayat, A. (2014). Interrelationship of biases: effect investment decisions ultimately. Theoretical and Applied Economics, 21(6), 85110.

Kahneman, D., \& Tversky, A. (1979). Prospect theory: An analysis of decision under risk. Econometrica, 47(2), 263-291.

Kimeu, C.N., Onyango, W. \& Rotich, G. (2016). Behavioral factors influencing investment decisions among individual investors in Nairobi securities exchange. Strategic Journal of Business and Change Management, 3(4), pp 1243-1258.

Lin, Y.-E., Fan, W.-M., \& Chih, H.-H. (2014). Throwing good money after bad? The impact of the escalation of commitment of mutual fund managers on fund performance. Journal of Behavioral Finance, 15(1), 1-15.

Morris, S., \& Shin, H. (2002). Social value of public information. American Economic Review, 92(5), 1521-1534. Retrieved from http://www.ingentaconnect.com/content/aea/aer/2002/00000092/00000005/art00012

Nairobi Stock Exchange - NSE (2016). Annual Report 2009, Nairobi: Nairobi Stock Exchange.

Patrick I, D. Z., Tavershima, A., \& Eje, E. B. (2017). Effect of financial information on investment decision making by shareholders of banks in Nigeria. IOSR Journal of Economics and Finance, 08(03), 20-31. http://doi.org/10.9790/5933-0803032031

Pradikasari, E. \& Isbanah, Y. (2018). Pengaruh financial literacy, illusion of control, overconfidence, risk tolerance, dan risk perception terhadap keputusan investasi pada mahasiswa di Kota Surabaya, Jurnal Ilmu Manajemen(JIM), Vol. 6 No. 4, pp. 108-117. 
Qadri, S. U., \& Shabbir, M. (2014). An empirical study of overconfidence and illusion of control biases, impact on investor"s decision making: An evidence from ISE. European Journal of Business and Management, 6(14), 38-44.

Qureshi, S. A., Rehman, K. ur, \& Hunjra, A. I. (2014). Factors affecting investment decision making of equity fund managers factors affecting investment decision making of equity fund managers. Wulfenia Journal, 19(10), 280-291.

Raheja, S. \& Dhiman, B. (2020). How do emotional intelligence and behavioral biases of investors determine their investment decisions? Rajagiri Management Journal, 14(1), pp. 35-47.

Rasool, N. \& Ullah, S. (2019). Financial literacy and behavioural biases of individual investors: empirical evidence of Pakistan stock exchange. Journal of Economics, Finance and Administrative Science, 25(50), pp. 261-278.

Ratnadi, N. M. D., Widanaputra, A. A. G. P. \& Putra, I. N. W. A. (2020). Behavioral Factors Influencing Investment DecisionMaking By College Student: An Empirical Study In Bali Province, Indonesia.

Rihaz, S., Ahamed, R., Parkash, R. \& Ahamed, R.J. (2020). Determinants of Stock Market Investors' Behavior in COVID-19: A Study on the Pakistan Stock Exchange. International Journal of Disaster Recovery and Business Continuity, 11(3), pp. 977 990.

Ritter, J. R. (2003). Behavioral finance. Pacific-Basin Finance Journal, 11(4), 429-437.

Thaler.R. and Shefrin,H. (1981). An economic theory of self control. Journal of Political Economy, 89 (2), pp 392-410.

Waweru, N., M., Munyoki, E., and Uliana, E. (2008). The effects of behavioural factors in investment decision-making: a survey of institutional investors operating at the Page 75 Nairobi Stock Exchange. International Journal of Business and Emerging Markets, 1(1), 24-41. 